\title{
Effect of distraction arthroplasty on osteoarthritic goat models of the articular cartilage
}

\author{
Rizky N.H. Putro, Heka Priyamurti, Andri M.T. Lubis \\ Department of Orthopedics and Traumatology, Faculty of Medicine, Universitas Indonesia, Jakarta, Indonesia
}

\begin{abstract}
Abstrak
Latar belakang: Osteoartritis (OA) adalah kelainan sendi lutut degeneratif tersering, jumlah pasien $O A$ semakin bertambah dengan bertambahnya harapan hidup. Artroplasti distraksi adalah sebuah alternatif yang relatif lebih tidak invasif untuk tatalaksana $O A$ dengan menghilangkan stres mekanis dan mempertahankan tekanan intermiten cairan sendi, sehingga menghentikan siklus kerusakan pada OA. Penelitian ini bertujuan mempelajari perubahan anatomi dan histopatologi setelah artroplasti distraksi pada model hewan osteoartritis.
\end{abstract}

Metode: Penelitian dilakukan pada 32 lutut kambing (16 kambing) yang terlebih dahulu diinduksi secara mekanis menjadi $O A$ dengan menisektomi lateral. Selama masa penelitian, 6 kambing mati. Artroplasti distraksi dilaksanakan menggunakan fiksasi eksterna pada 10 lutut selama 4 minggu, dan 10 lutut kontralateral dibiarkan, kemudian diperiksa secara anatomis dan histopatologis untuk diperbandingkan mengunakan staging International Cartilage Repair Society (ICRS) dan skoring Osteoarthritis Research Society International (OARSI). Perbedaan anatomis dan histopatologis diuji kemaknaannya menggunakan uji Wilcoxon.

Hasil: Terdapat perburukan secara anatomi dan histopatologi pada lutut yang diberikan perlakuan. Nilai median perbandingan secara makroskopis dengan staging ICRS berbeda bermakna $(1,5$ vs 2,5; $p<0,002)$. Perbandingan secara histopatologi dengan skoring OARSI berbeda bermakna (6 vs 10; $p<0,002)$.

Kesimpulan: Arthroplasti distraksi pada model OA kambing dalam penelitian ini, tidak memberikan perbaikan, melainkan memperburuk OA. Penelitian lebih lanjut diperlukan untuk memberikan dasar biologis yang kuat dari artroplasti distraksi sebagai terapi alternatif untuk OA. (Med J Indones. 2013;22:64-9)

\begin{abstract}
Background: Osteoarthritis (OA) is the most common knee degenerative disease, the number of OA patients increases along with the increase of life expectancy. Distraction arthroplasty is a less invasive alternatif for OA management by releaving mechanical stress while maintaining intermitten joint fluid pressure changes, thus halting the OA destructive cycle and inducing repair. This study aims to evaluate the anatomical and histopathological changes after distraction arthroplasty on osteoarthritic animal models.

Methods: The study was performed on 32 goat stiffle joint (16 goats) with mechanically induced OA by lateral meniscectomy. During the study 6 goats were decreased. Distraction arthroplasty was performed using external fixation on 10 knees for 4 weeks, and the contralateral knees left untreated. The knees were anatomically and histopathologically examined using International Cartilage Repair Society (ICRS) staging and Osteoarthritis Research Society International (OARSI) scoring. The differences of the anatomical and histopathological changes are tested for significance using the Wilcoxon test.

Results: There was anatomical and histopathological worsening of the OA on treated knees. The anatomical difference assessed using ICRS stage gave median values of 1.5 and 2.5 respectively $(\mathrm{p}<0.002)$. The histopathological difference assessed using OARSI scoring was significant (6 vs $10 ; \mathrm{p}<0.002)$.

Conclusion: Distraction arthroplasty in OA goat models in this study, worsens the OA instead of inducing repair. Further studies are required to find out a convincing biological basis of distraction arthroplasty as an alternative treatment for OA. (Med J Indones. 2013;22:64-9)
\end{abstract}

Keywords: Animal model, distraction arthroplasty, osteoarthritis

Knee osteoarthritis (OA) affects a substantial proportion of patient over the age of 55 seeking advice to a physician. ${ }^{1}$ Increasing life expectancy and body mass index are likely to increase this proportion over the years. Conservative treatment in mild knee OA includes lifestyle changes, physical, and pharmacological therapy. Severe cases of knee OA however, can be disabling rendering the patient unable to perform daily activities. ${ }^{2}$

Severe pain and functional disability on late $\mathrm{OA}$ are the primary indication for total knee replacement (TKR). ${ }^{3}$
TKR is the treatment of choice due to its ability to return the patients to their former activity. In the United Kingdom, between the year 1991-2000, around 33.000 TKRs were performed each year. Last year, however, this figure has increased over 58.000 surgeries. ${ }^{4}$

TKR itself is not a risk free procedure. Complications such as infection and deep vein thrombosis still lurk after TKR surgery. Patients must also prepare for revision surgery 10-15 years later. ${ }^{5}$ Therefore endeavours to seek better treatment never ceased. 
An alternative treatment that alleviates pain and increase the joint function would be quite beneficial. A biomechanical approach for OA under research is by means of unloading. ${ }^{6}$ Joint distraction also known as distraction arthroplasty is an alternative based on that principal, a relatively less invasive and less costly alternative. Long term efficacy of distraction arthroplasty on ankle joint OA gives hope to similar approaches towards knee OA. ${ }^{7}$

Several theories becomes the basis for this treatment alternative. It is mentioned that the articular cartilage on OA has repair activities. ${ }^{7}$ The repair activity will be more efficaceous when the mechanically damaged cartilage is unloaded thus preventing further damaged. ${ }^{6}$ Intermitten synovial pressure also plays a role by reducing catabolic cytokins IL-1 and TNF- $\alpha$ and increasing proteoglycan production. ${ }^{8,9}$

Distraction arthroplasty attempts to generate a conducive environment for the articular cartilage by relieving mechanical stress whilst providing intermittent synovial pressure. This will eventually shift the balance from deterioration towards repair thus breaking the destructive cycle of OA..$^{7-10}$

Nevertheless, there still in-adequate data showing that repair does happen after distraction arthroplasty. Several animal studies show different results. ${ }^{11-14}$ It has only been performed on a pilot study on humans. ${ }^{15}$ Some authors also doubt the efficacy of this method. ${ }^{16}$

This research aims to study the anatomical and histopathological changes after distraction arthroplasty on osteoarthritic animal models. This research used the goat animal model because it has similar biomechanics to human knee. ${ }^{17,18}$ Animals of this genus is said to have a congruency in one third of the human knee size. ${ }^{19}$ The goat also has thicker and easier to study cartilage, and relatively cost effective. ${ }^{18,20}$

\section{METHODS}

This research was conducted in a post-test only with control group experimental design. The controls used were the contra-lateral joints. The research was carried out for six months using the facilities at the Institut Pertanian Bogor (IPB) Veterinary Teaching Hospital.

\section{Subjects}

Ten male goats (Capra aegagrus hircus) aged 2 years weighing 25-30 kg were used in this research. ${ }^{21}$ The intervention group was the left stifle joints of the subjects and the control group was the right stifle joints. These goats were kept in three moderate animal cages sized $5 \times 5 \mathrm{~m}^{2}$ and stayed for two weeks without intervention for acclimatization. All subjects underwent anteroposterior radiography to ensure there are no previous pathologies.

\section{OA induction}

Induction into OA for the animal models was performed by means of lateral meniscectomy. Both stifle joints of the subjects were meniscectomized and awaited for six weeks. Lateral meniscectomy is chosen to induce OA due to its proven efficacy. ${ }^{22-24}$

\section{Distraction}

The distraction device used in this research was the peri-prosthetic external fixator device designed by Ismail Hadisoebroto Dilogo (patent pending) consisting of a rod and two holders. The device was placed transarticularly through the knee joint at the lateral side (Figure 1). The device was then distracted $3 \mathrm{~mm}$ more than the normal joint in extension position as the lowest load in a stiffle joint. ${ }^{25}$ Distraction was performed for four weeks.

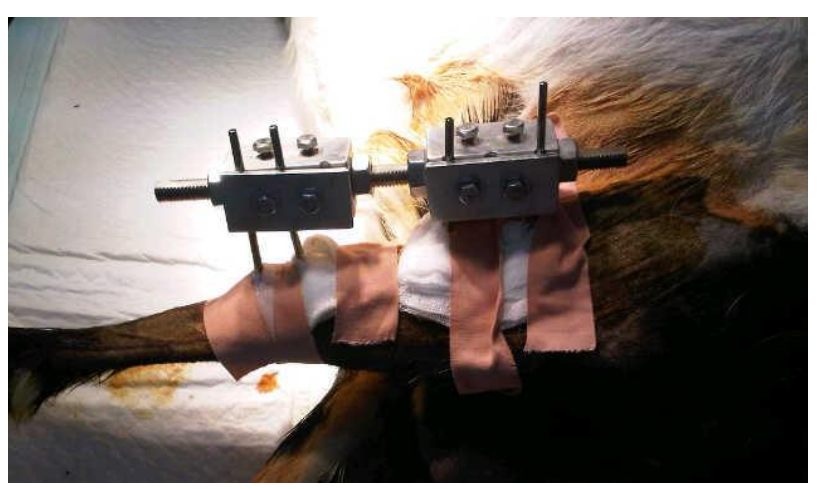

Figure 1. Device placed transarticular at the lateral side of the stifle joint

\section{Evaluation}

After fourweeks of distraction, the peri-articular external fixation devices are removed. The anatomical changes were then evaluated using the International Cartilage Repair Society (ICRS) classification. ${ }^{26}$ Afterwards the cartilages from the proximal tibias are harvested and stained using haematoxylin-eosin and evaluated using Osteoarthritis Research Society International (OARSI) osteoarthritis cartilage histopathology assessment system which yields scoring from grading multiplied by staging. ${ }^{27}$ 


\section{Statistical analysis}

The nature of the grading and scoring used in this research were semi-quantitative. Therefore, statistical analysis were performed using the Wilcoxon ranksum test.

\section{Ethical clearance}

The methods above was proposed and reviewed for ethical approval beforehand. Ethical approval was obtained from the Animal Care and Use Committee IPB Veterinary Teaching Hospital number 04-2011 RSH-IPB.

\section{RESULTS}

\section{Anatomical changes}

The anatomical changes after removal of the periarticular external fixation device were evaluated using ICRS. They are shown in table 1.

The results show worsening at the distraction group as indicated by higher grades of ICRS (Figure 2). A box plot showing comparison of the median between the two groups median of ICRS grade in control distraction group was significantly higher than control group (2.5 vs $1.5 ; \mathrm{p}<0.005)$.

\section{Histopathological changes}

After anatomical evaluation, OARSI staging is performed by measuring the horizontal extent of cartilage involved. The cartilages are harvested and stained using haematoxylin-eosin from which grading is obtained. Scoring is then performed by OARSI using scoring system which are obtained by multiplying the staging and grading. Results are shown in table 2 .

Histopathological scoring using OARSI score show similar results with the anatomical grading using ICRS. The distraction group show worsening as shown by the higher score coparet to control group (10 vs $6 ; p<0.02$ ).

Table 1. Anatomical evaluation result using ICRS

\begin{tabular}{ccc}
\hline No & Control & Distraction \\
\hline 1 & 2 & 3 \\
2 & 2 & 3 \\
3 & 2 & 3 \\
4 & 1 & 2 \\
5 & 1 & 2 \\
6 & 2 & 3 \\
7 & 1 & 2 \\
8 & 1 & 2 \\
9 & 1 & 2 \\
10 & 2 & 3 \\
\hline
\end{tabular}

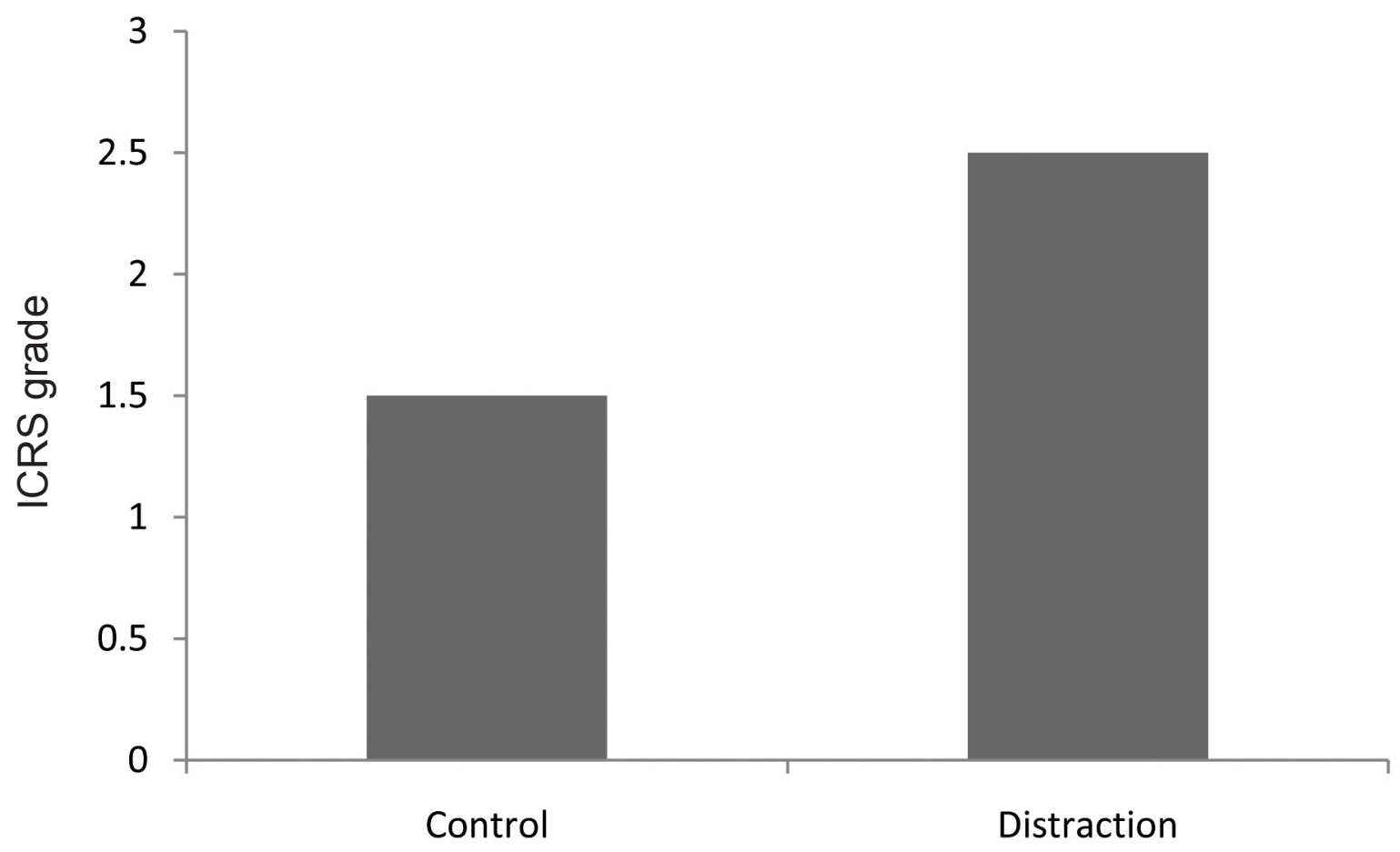

Figure 2. Graph showing median comparison of ICRS grade between the two groups 
Table 2. Staging and grading using OARSI system which yields scoring

\begin{tabular}{ccccccc}
\hline & \multicolumn{2}{c}{ Control group } & \multicolumn{2}{c}{ Distraction group } & \multicolumn{2}{c}{ Scoring } \\
\hline No & Stage & Grade & Stage & Grade & Control & Distraction \\
\hline 1 & 3 & 3 & 4 & 4 & 9 & 16 \\
2 & 1 & 3 & 2 & 4 & 3 & 8 \\
3 & 2 & 3 & 4 & 4 & 6 & 16 \\
4 & 3 & 2 & 4 & 3 & 6 & 12 \\
5 & 3 & 2 & 3 & 3 & 6 & 9 \\
6 & 1 & 3 & 2 & 4 & 3 & 8 \\
7 & 2 & 2 & 3 & 3 & 4 & 9 \\
8 & 3 & 2 & 3 & 3 & 6 & 9 \\
9 & 2 & 2 & 4 & 4 & 4 & 16 \\
10 & 2 & 3 & 3 & 4 & 6 & 12 \\
\hline
\end{tabular}

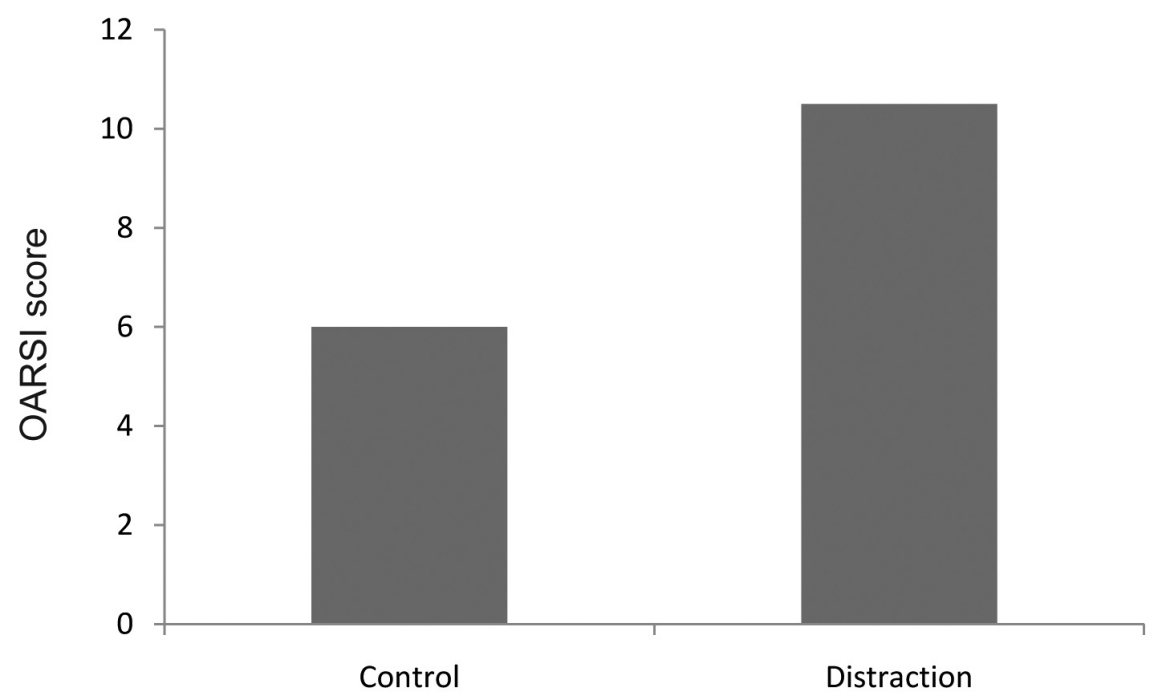

Figure 3. Graph showing median comparison of OARSI scores between the two groups

\section{DISCUSSION}

\section{Animal model}

Some studies showed that small and medium animals were frequently used, yet there has never been a study on distraction using the goat model. ${ }^{12-14}$ The choice of medium sized animals, goat stifles, in this study was based on their biomechanical similarities with the human knee. ${ }^{18,25}$ The stifle joint of this genus is said to be congruent to one third of the human knee. ${ }^{19}$ Lateral meniscectomy was chosen to induce OA due to its efficacy. ${ }^{22-24}$

\section{Distraction arthroplasty}

Distraction arthroplasty was based on the theory that the articular cartilage in OA has self repair activity. ${ }^{7,10}$ It is expected that by distraction, the mechanically damaged cartilage is unloaded, therefore preventing further damage. ${ }^{6,28}$ The intermittent synovial pressure is maintained by external fixation allowing minute movement, that was proven in vitro to reduce the production of catabolic cytokines IL- 1 dan TNF- $\alpha$ and increase proteoglycan synthesis. ${ }^{8,9,29}$ This could also trigger growth factors stimulating cartilage repair. ${ }^{30}$

Long term beneficial results of ankle distraction have been reported. ${ }^{7,10}$ Several animal studies using external fixation show the same results. ${ }^{12,13}$ The latest report of an open one year pilot study from the pioneers of knee distraction arthroplasty also yields beneficial result. ${ }^{15}$

Several literatures, however, doubts the biological basis for this treatment, due to the long known fact that joint immobilization damages the articular cartilage. ${ }^{16}$ 
Karadam et al reported no beneficial effects of distraction on a study using rabbits. ${ }^{11}$

On this research, the anatomical and histopathological results show worsening as evaluated by the respective grading and scoring $(\mathrm{p}<0.05)$. Therefore, a significant difference exists between the control and intervention groups though the result was the other way around. Instead of inducing repair, the distraction arthroplasty on this research worsens the OA.

The first principle of unloading in this research has been fulfilled by a $3 \mathrm{~mm}$ distraction. ${ }^{14}$ The position of external fixation is on the lowest load of the goat stifle. ${ }^{25}$ The use of external fixation not allowing flexion and extension as the previous studies did, to give intermittent hydrostatic pressure could be the culprit of worsening. ${ }^{12-14}$ However, the study by Karadam et al using a device allowing flexion and extension still gave no benefits. ${ }^{11}$ Theoritecally, the opposite result in this research could also happen due to continuous distraction on a moving joint causes chondrocytes morphological changes inducing changes in celluler biochemistry and matrix metabolism. ${ }^{31}$

Obtaining histopathological preparations immediately after distraction, instead of allowing weight bearing first, also affects the results, as shown in the result difference in two rabbit model studies. ${ }^{11,13}$

\section{Strength and limitations}

The strength of this research would be the use of larger animal models mimicking the human knee. ${ }^{17,19}$ The controls used in this research were the contralateral stifle joint, thus other than the intervention; both groups receive the same treatment. A possible bias would be more use of the control group by the subject therefore the control show worse results, which did not happen in this research. Other researches also use contralateral joints on OA research. ${ }^{11,32}$

Limitations of this research were the distraction device design and research time. The design allows distraction and oscillation, but the oscillation is not measurable to give the intermittent fluid pressure meant for this research. ${ }^{8,9,15}$ The time in this research was relatively short compared to other researches showing benefits after long periods post-distraction. ${ }^{13,15}$

In conclusion, the use of monoplanar distraction in this research needs to be redesigned to give adequate oscillation to provide intermittent hydrostatic pressure, thus yielding better result. ${ }^{12,13}$ Further research should be also performed on how much intermittent hydrostatic pressure is adequate to induce cartilage repair. ${ }^{8,9,33}$
Distraction arthroplasty as an alternative treatment still requires further research on animal models before clinical studies can be performed on human subjects due to lack of solid biological basis.

\section{Acknowledgments}

Our greatest appreciation goes to DRPM Universitas Indonesia who provided funds for the project. We also confer our gratitude to IPB Veterinary Teaching Hospital for providing us excellent animal care during the study and the required facilities.

\section{REFERENCES}

1. Felson DT. Osteoarthritis of the knee. N Engl J Med. 2006;354:841-8.

2. Gidwani S, Fairbank A. The orthopaedic approach to managing osteoarthritis of the knee. BMJ. 2004;329:1220-4

3. Harwin SF. Indications and patient selection. In: Scuderi GR, Tria AJ, editors. Surgical Techniques in total knee arthroplasty. New York: Springer-Verlag; 2002.p. 3-8.

4. Martyn P, Borroff M, Gregg P, et al. National Joint Registry for England and Wales 9th Annual Report [Internet]. 2012. Available from: http://www.njrcentre.org.uk/NjrCentre/ Portals/0/Documents/England/Reports/9th_annual_report/ NJR 9th Annual Report 2012.pdf.

5. Schemitsch EH, Thornhill TS. Management of bone loss in revision arthroplasty. In: Scuderi GR, Tria AJ, editors. Surgical techniques in total knee arthroplasty. New York: Springer-Verlag; 2002.p.393-9.

6. Lafeber FP, Intema F, van Roermund PM, Marijnissen AC. Unloading joints to treat osteoarthritis, including joint distraction. Curr Opin Rheumatol. 2006;18(5):519-25.

7. Marijnissen AC, van Roermund PM, van Melkebeek J, et al. Clinical benefit of joint distraction in the treatment of severe osteoarthritis of the ankle: proof of concept in an open prospective study and in a randomized controlled study. Arthritis Rheum. 2002;46(11):2893-902.

8. Fioravanti A, Collodel G, Petraglia A, Nerucci F, Moretti E, Galeazzi M. Effect of hydrostatic pressure of various magnitudes on osteoarthritic chondrocytes exposed to IL1beta. Indian J Med Res. 2010;132:209-17.

9. Elder BD, Athanasiou KA. Hydrostatic pressure in articular cartilage tissue engineering: from chondrocytes to tissue regeneration. Tissue Eng Part B Rev. 2009;15(1):43-53.

10. Tellisi N, Fragomen AT, Kleinman D, O'Malley MJ, Rozbruch SR. Joint preservation of the osteoarthritic ankle using distraction arthroplasty. Foot Ankle Int. 2009;30(4):318-25.

11. Karadam B, Karatosun V, Murat N, Ozkal S, Gunal I. No beneficial effects of joint distraction on early microscopical changes in osteoarthrotic knees. A study in rabbits. Acta Orthop. 2005;76(1):95-8.

12. Yanai T, Ishii T, Chang F, Ochiai N. Repair of large fullthickness articular cartilage defects in the rabbit: the effects of joint distraction and autologous bone-marrow-derived mesenchymal cell transplantation. J Bone Joint Surg Br. 2005;87(5):721-9. 
13. Nishino T, Chang F, Ishii T, Yanai T, Mishima H, Ochiai N. Joint distraction and movement for repair of articular cartilage in a rabbit model with subsequent weight-bearing. J Bone Joint Surg Br. 2010;92(7):1033-40.

14. van Valburg AA, van Roermund PM, Marijnissen AC, et al. Joint distraction in treatment of osteoarthritis (II): effects on cartilage in a canine model. Osteoarthritis Cartilage. 2000;8(1):1-8.

15. Intema F, van Roermund PM, Marijnissen AC, et al. Tissue structure modification in knee osteoarthritis by use of joint distraction: an open 1-year pilot study. Ann Rheum Dis. 2011;70(8):1441-6.

16. Hunziker EB. Articular cartilage repair: basic science and clinical progress. A review of the current status and prospects. Osteoarthritis Cartilage 2002;10(6):432-63.

17. Mastbergen SC, Lafeber FPJG. Animal models of osteoarthritis-why choose a larger model? US Musculoskeletal Review. 2009;4:11-4.

18. Miot S, Brehm W, Dickinson S, et al. Influence of in vitro maturation of engineered cartilage on the outcome of osteochondral repair in a goat model. Eur Cell Mater. 2012;23:222-36.

19. Osterhoff G, Löffler S, Steinke H, Feja C, Josten C, Hepp P. Comparative anatomical measurements of osseous structures in the ovine and human knee. Knee 2011;18(2):98-103.

20. Pearce AI, Richards RG, Milz S, Schneider E, Pearce SG. Animal models for implant biomaterial research in bone: a review. Eur Cell Mater. 2007;13:1-10.

21. Poole R, Blake S, Buschmann M, et al. Recommendations for the use of preclinical models in the study and treatment of osteoarthritis. Osteoarthritis Cartilage 2010;18 Suppl 3:S10-6.

22. Mcnicholas MJ, Rowley DI, Mcgurty D, et al. Total meniscectomy in adolescence. A thirty-years follow up. J Bone Joint Surg Br. 2000;82(2):217-21.
23. Englund M, Lohmander LS. Risk factors for symptomatic knee osteoarthritis fifteen to twenty-two years after meniscectomy. Arthritis Rheum. 2004;50(9):2811-9.

24. Smith MM, Cake MA, Ghosh P, Schiavinato A, Read, RA, Little CB. Significant synovial pathology in a meniscectomy model of osteoarthritis: modification by intra-articular hyaluronan therapy. Rheumatology 2008;47(8):1172-8.

25. Burger C, Mueller M, Wlodarczyk P, et al. The sheep as a knee osteoarthritis model: early cartilage changes after meniscus injury and repair. Lab Anim. 2007;41(4):420-31.

26. Brittberg M, Winalski CS. Evaluation of cartilage injuries and repair . J Bone Joint Surg Am. 2003;85:58-69.

27. Pritzker KPH, Gay S, Jimenez SA, et al. Osteoarthritis cartilage histopathology: grading and staging. Osteoarthritis Cartilage 2006;14(1):13-29.

28. Brandt KD. Etiopathogenesis. In: Brandt KD, editor. Diagnosis and nonsurgical management of osteoarthritis. New York: Professional Communications; 2010. p. 53-60.

29. Grodzinsky AJ, Levenston ME, Jin M, Frank EH. Cartilage tissue remodelling in response to mechanical forces. Annu Rev Biomed Eng. 2000;2:691-713.

30. Temenoff JS, Mikos AG. Review: tissue engineering for regeneration of articular cartilage. Biomaterials. 2000;21(5):431-40.

31. Hung S, Nakamura K, Shiro R, Tanaka K, Kawahara H, Kurokawa T. Effects of continuous distraction on cartilage in a moving joint: An investigation on adult rabbits. J Orthop Res. 1997;15(3):381-90.

32. Manicourt D, Pita J. Progressive depletion of hyaluronic acid in early experimental osteoarthritis in dogs. Arthritis Rheum. 1988;31(4):538-44.

33. Huang CC, Hagar KL, Frost LE, Sun Y, Cheung HS. Effects of cyclic compressive loading on chondrogenesis of rabbit bone-marrow derived mesenchymal stem cells. Stem cells 2004;22(3):313-23. 